\title{
Reduced Cyclic AMP Production in Fragile $X$ Syndrome: Cytogenetic and Molecular Correlations
}

\author{
ELIZABETH BERRY-KRAVIS, MARK HICAR, AND RITA CIURLIONIS
}

Departments of Pediatrics [E.B.-K., M.H., R.C.], Neurology[E.B.-K.], and Biochemistry[E.B.-K.], RUSH-Presbyterian-St. Luke's Medical Center, Chicago, Illinois 60612

\begin{abstract}
The cAMP cascade is an intracellular signal transduction system thought to be important for neuronal regulation and information storage. cAMP production is reduced in platelets from patients with fragile $\mathrm{X}$ syndrome. In the present study we assayed cAMP metabolism, Xq27.3 fragile site percentages, size of amplification mutation in fragile $\mathrm{X}$ mental retardation- 1 gene (FMR-1), and FMR-1 mRNA levels in 21 lymphoblastoid cell lines (LCL) from fragile $X$ patients. cAMP production was diminished in fragile $X$ LCL relative to controls $(n=20)$ when cells were assayed in prostaglandin $\mathrm{E}_{1}(74 \%, p<0.02)$ and in forskolin $(64 \%, p<0.1)$ although the difference was statistically significant only in prostaglandin $\mathrm{E}_{1}$. The length of the FMR-1 amplification mutation correlated with measures of cAMP production which were unassociated with receptor activation $(r=$ $-0.53, p=0.02$, and $r=-0.48, p=0.03$, for unstimulated and forskolin-stimulated cAMP production, respectively). In fragile $X$ LCL, fragile site percentages did not correlate with any measure of cAMP production. All fragile $\mathrm{X} \mathrm{LCL}$ showed ab-
\end{abstract}

\section{ABSTRACT}

sence of FMR-1 mRNA. These data suggest that diminished cAMP production in fragile $X$ tissues may be linked to the fragile $\mathrm{X}$ amplification mutation, either as a result of influences of the mutation on FMR-1 expression or on transcription of other genes downstream from FMR-1. (Pediatr Res 38: 638-643, 1995)

\section{Abbreviations}

FMR-1, fragile $X$ mental retardation- 1 gene, the fragile $X$ gene

LCL, lymphoblastoid cell lines

PGE $_{1}$, prostaglandin $\mathrm{E}_{1}$

FSK, forskolin

$\mathbf{G}_{\mathbf{s}}$, GTP-binding stimulatory regulatory subunit of adenylate cyclase

IBMX, 1-isobutyl-3-methylxanthine

PCR, polymerase chain reaction

RT, reverse transcription
The cAMP cascade is a second messenger cascade which is thought to regulate neuronal functions and produce short-term sensitization (or neuronal memory) through the following mechanism (for reviews, see Refs. 1 and 2). Cell membrane receptors bind neurotransmitters or other neuroactive ligands causing interaction of receptor proteins with signal-transducing GTP-binding regulatory subunits $\left(\mathrm{G}_{\mathrm{s}}\right.$ or $\mathrm{G}_{\mathrm{i}}$ for stimulatory or inhibitory, respectively) of adenylate cyclase. Regulatory subunits then interact with a catalytic subunit of adenylate cyclase to increase or decrease production of cAMP. Intracellular cAMP binds to regulatory subunits of cAMP-dependent protein kinases and activates these kinases resulting in phosphorylation and activation (or deactivation) of their protein or enzyme substrates and, thus, modification of neuronal synaptic

Received August 15, 1994; accepted May 1, 1995.

Correspondence and reprint requests: Elizabeth Berry-Kravis, M.D., Ph.D., Department of Pediatrics, RUSH-Presbyterian-St. Luke's Medical Center, 1725 West Harrison, Suite 718, Chicago, IL 60612.

Supported in part by the Brain Research Foundation at the University of Chicago and the University Committee on Research, RUSH Medical College. properties. Phosphodiesterases hydrolyze cAMP and phosphatases dephosphorylate protein substrates.

The cAMP cascade can produce long-term changes in neuronal responsiveness (3), presumably via induction of phosphorylation of transcription factors which bind AP-2 or CRE consensus sites in the promoters of specific genes, thereby enhancing or inhibiting transcription of selective groups of genes. This process is thought to play a role in long-term sensitization in simple organisms and learning in higher organisms (4).

Biochemical lesions affecting regulation or activity of this cascade in lower organisms and humans, as expected, produce learning or memory deficits. In Aplysia, blockade of cAMP synthesis or injection of inhibitors of PK-A prevents short-term sensitization of the gill withdrawal reflex and longer-term changes in protein synthesis (5). Learning-deficient Drosophila mutants (6) have decreased activity of various cAMP cascade proteins including phosphodiesterase (dunce), catalytic subunit of adenylate cyclase (rutabaga), neurotransmitter production (Ddc), and $\mathrm{G}_{\mathrm{s}}$ regulatory subunit (turnip). In humans, patients 
with type Ia pseudohypoparathyroidism and myotonic dystrophy have learning deficiency and diminished activity and genetic lesions of the $\mathrm{G}_{\mathrm{s}}$ regulatory subunit of adenylate cyclase (7) and a cAMP-dependent protein kinase (8), respectively. Previous studies from our laboratory have demonstrated diminished cAMP production in platelets from patients with fragile $\mathrm{X}$ syndrome relative to normal controls and patients with nonspecific mental retardation or autistic disorder $(9,10)$.

Fragile $\mathrm{X}$ syndrome is an $\mathrm{X}$-linked mental retardation syndrome associated with a folate-sensitive fragile site at band $\mathrm{Xq} 27.3$. It is the most common inherited mental retardation syndrome, with an incidence of 1:1250 for males (11). In addition to mental retardation, patients with fragile $\mathrm{X}$ syndrome manifest variable facial dysmorphism, large ears, long narrow face, and testicular enlargement. The fragile site serves mainly as a marker for the presence of a large fragile $\mathrm{X}$ mutation (full mutation), which is now known to consist of an amplification of a variable size unstable trinucleotide repeat sequence (CGG) present in the first exon of the fragile $\mathrm{X}$ gene, FMR-1 (12). Small amplifications ( $<200$ repeats) of this sequence (premutation) do not produce fragile $\mathrm{X}$ syndrome but are unstable and may expand to the full mutation when passed by a female to her offspring (13). Large amplifications ( $>300$ repeats) of this sequence result in hypermethylation of the FMR-1 promoter region (14), inactivation of the gene, loss of expression of the FMR-1 mRNA (15) and protein (16), and hence, the clinical syndrome. Because of the instability of the amplified sequence, mosaicism for size and/or methylation status of the mutation is common in fragile $\mathrm{X}$ patients (15), and some patients with borderline mutation size (200-300 repeats) exhibit only partial methylation and tend to be "higher functioning" (17). Although absence of the FMR-1 protein appears to produce cognitive dysfunction, its role in neural function and/or development is not known. In this study, LCL were used to examine cAMP production in a second fragile $\mathrm{X}$ tissue and to explore relationships between cAMP production and cytogenetic and molecular findings in fragile $\mathrm{X}$ cells in a standardized setting free of dietary or drug effects.

\section{METHODS}

Patients. Patients with fragile $\mathrm{X}$ syndrome were recruited from the Fragile X Clinic at RUSH-Presbyterian-St. Luke's Medical Center or from the Fragile X Association of America. All patients in the fragile $X$ group were affected males (age range $4-50, n=21$ ) with a clinical phenotype consistent with the syndrome. Mental disability, as expected, was quite variable with mental retardation in 20 patients (4 severe, 11 moderate, 5 mild) and 1 patient with an IQ in the normal range. All patients had multiple behavioral traits associated with fragile X syndrome; all had attentional difficulties and some degree of hyperactivity. The majority also had a high level of anxiety, eye aversion, and perseverative speech. Sixteen patients manifested typical facial dysmorphism with large or prominent ears, long face, and midfacial hypoplasia. The remaining five manifested some to none of these features. Confirmation of the diagnosis in each patient was made by cytogenetic testing demonstrating a significant percentage $(>10 \%)$ of folate-sensitive fragile sites at $\mathrm{Xq} 27.3$ or by direct DNA analysis of FMR-1 demonstrating a full mutation. Controls were unmedicated, normally intelligent male and female subjects (age range 6-60 y).

Cell culture and cAMP measurement. Blood $(10 \mathrm{~mL}$ in heparinized tubes) was obtained from fragile $\mathrm{X}$ patients or controls. Lymphocytes were isolated on Ficoll-Paque (Pharmacia, Piscataway, NJ) gradients, transformed with EBV, and grown in RPMI 1640 (Life Technologies, Inc., Gathersburg, MD) containing $10 \%$ FCS. Cells were passaged $6 \mathrm{~d}$ before assay and fed $2 \mathrm{~d}$ before assay. They were $80-90 \%$ confluent at the time of assay. Triplicate tubes containing lymphoblastoid cell suspensions were incubated with appropriate drugs for 30 min at $35^{\circ} \mathrm{C}$. IBMX $(1 \mathrm{mM})$ was used to inhibit phosphodiesterase, $\mathrm{PGE}_{1}(10 \mu \mathrm{M})$ to measure receptor-dependent stimulation of cAMP production, and FSK $(50 \mu \mathrm{M})$ to directly activate the catalytic subunit of adenylate cyclase. Although several agents $\left(\mathrm{PGE}_{1}\right.$, isoproterenol, and chloroadenosine) stimulated CAMP production in LCL via a receptor-mediated mechanism, PGE $_{1}$ was chosen for use in LCL studies because it was the most potent cAMP stimulator and for continuity with studies of $\mathrm{PGE}_{1}$-stimulated cAMP production in platelets from fragile $\mathrm{X}$ patients. CAMP was extracted as described elsewhere (9). Protein was measured by the method of Lowry et al. (18) and cAMP by RIA (19).

During early experiments designed to characterize cAMP responsiveness of LCL, several lines were assayed two to three times, and some interassay variability in the magnitude of cAMP production values measured was noted, with as much as 2-3-fold differences in measurements for the same line in different assays. The relative cAMP production between lines, however, was generally constant between assays (lines with highest CAMP levels were always highest despite changes in the magnitude of the values). To minimize effects of interassay variability on the results of this study, 8-11 LCL were included in each cAMP assay, with roughly even numbers of fragile $\mathrm{X}$ and control LCL in each assay. Each line was assayed once (in triplicate) for this study. Molecular and cAMP studies were performed on LCL of identical early passage and cytogenetic studies were completed within several passages.

Cytogenetic analysis. LCL were diluted in M199 (Life Technologies, Inc.) with 5\% FCS $48 \mathrm{~h}$ before harvest, and 0.1 $\mu \mathrm{M}$ fluorodeoxyuridine was added $24 \mathrm{~h}$ before harvest. Colcemid $(1 \mu \mathrm{g} / 10 \mathrm{~mL})$ was added for the final hour of culture, and cells were pelleted, fixed, and subjected to routine cytogenetic analysis. Fragile site percentages were calculated based on 50-100 cells examined.

Southern blot and PCR analysis of FMR-1. Direct DNA analysis of the fragile $\mathrm{X}$ amplification mutation within FMR-1 was performed via Southern blot analysis. DNA was isolated from LCL according to standard methods. DNA (5-10 $\mu \mathrm{g})$ was digested with EcoRI (Boeringer Mannheim, Indianapolis, IN) or EcoRI + Eag I (New England Biolabs, Beverly, MA), and subjected to electrophoresis through agarose until the 1-kb marker was at $14 \mathrm{~cm}$. DNA was transferred to nylon membrane (Genescreen, DuPont NEN, Boston, MA), and blots were probed with radiolabeled StB12.3, $(14,20)$ which recognizes a 5.2-kb EcoRI fragment from FMR-1 in normal individuals. 
This fragment is enlarged $(5.3-5.8 \mathrm{~kb}$ in premutation carriers and $6-12 \mathrm{~kb}$ in full mutation carriers) and contains the trinucleotide repeat expansion mutation in fragile $X$ individuals. The enlarged segment of FMR-1 in individuals with a full mutation often appears as multiple bands or a smear due to presumed somatic instability of the amplified region $(14,15$, 20). Maximum, average, and minimum band or smear size for the mutated segment in DNA from fragile X LCL was determined by comparison with a 1-kb ladder and the normal $5.2-\mathrm{kb}$ band seen in lanes containing DNA from control individuals. EagI is sensitive to methylation at the FMR-1 locus and cuts only unmethylated DNA. EcoRI $+E a g I$ double digests were used to test for possible methylation mosaicism of the FMR-1 gene in fragile X LCL. If this were the case, additional lower molecular weight bands or smears would appear when the double digest was compared with the EcoRI digest, due to partial digestion of the EcoRI fragments by EagI. The fragment identified in DNA from normal males digested with EcoRI + $\mathrm{EagI}$ is $2.8 \mathrm{~kb}$. Normal FMR-1 CGG repeat sizes in DNA from control LCL were measured via PCR followed by gel electrophoresis and autoradiography of radiolabeled PCR products, exactly as described by Levinson et al. (21).

RT-PCR of FMR-1 CDNA. For RT-PCR (reverse transcription followed by PCR), total RNA was isolated from fresh pelleted cells according to the method of Chomczynski and Sacchi (22). Total cellular RNA $(5 \mu \mathrm{g})$ was subjected to RT-PCR according to the method of Pieretti et al. (15). Primers specific for FMR-1 were 4687 and 4747 (15) from positions 989-1009 and 1112-1134 of the FMR-1 cDNA sequence (12). Primers used for hypoxanthine-guanine phosphoribosyl transferase cDNA were 243 and 244 (23). PCR products were visualized on a $3 \%$ agarose gel stained with ethidium bromide.

\section{RESULTS}

Cyclic AMP production in fragile $X$ and control LCL. cAMP metabolism was examined in control $(n=20)$ and fragile $\mathrm{X}(n=21)$ LCL. cAMP production was diminished in fragile $X$ cells relative to controls in $\mathrm{PGE}_{1}(10 \mu \mathrm{M})+\mathrm{IBMX}$ $(74 \%, p=0.02)$, and FSK $(50 \mu \mathrm{M})+\operatorname{IBMX}(64 \%, p<0.1)$. cAMP production in control and fragile X LCL in the presence of various agents is compared with cAMP production in control and fragile X platelets (10) in Figure 1. Defective cAMP production was more evident in fragile $\mathrm{X}$ platelets, with $\mathrm{PGE}_{1-}$ and FSK-stimulated cAMP production $65 \%(p=0.001)$ and $53 \%(p=0.001)$ of the control group, respectively. cAMP production in IBMX alone in fragile X platelets was $50 \%$ of control $(p<0.05)$ but not different in LCL. FSK-stimulated cAMP production in fragile X LCL was not significantly different from controls due to high variability in FSK responsiveness between individual cell lines and the relatively low levels of stimulation intrinsic to the tissue. Nonetheless, the same basic pattern of cAMP production in fragile X samples (with magnitude of averaged FSK-stimulated production values lower than averaged $\mathrm{PGE}_{1}$-stimulated production values relative to averaged control data) was seen in both the platelet and LCL samples. Dose responses performed in a limited number of fragile $\mathrm{X}(n=6)$ and control $(n=6)$ LCL indicated
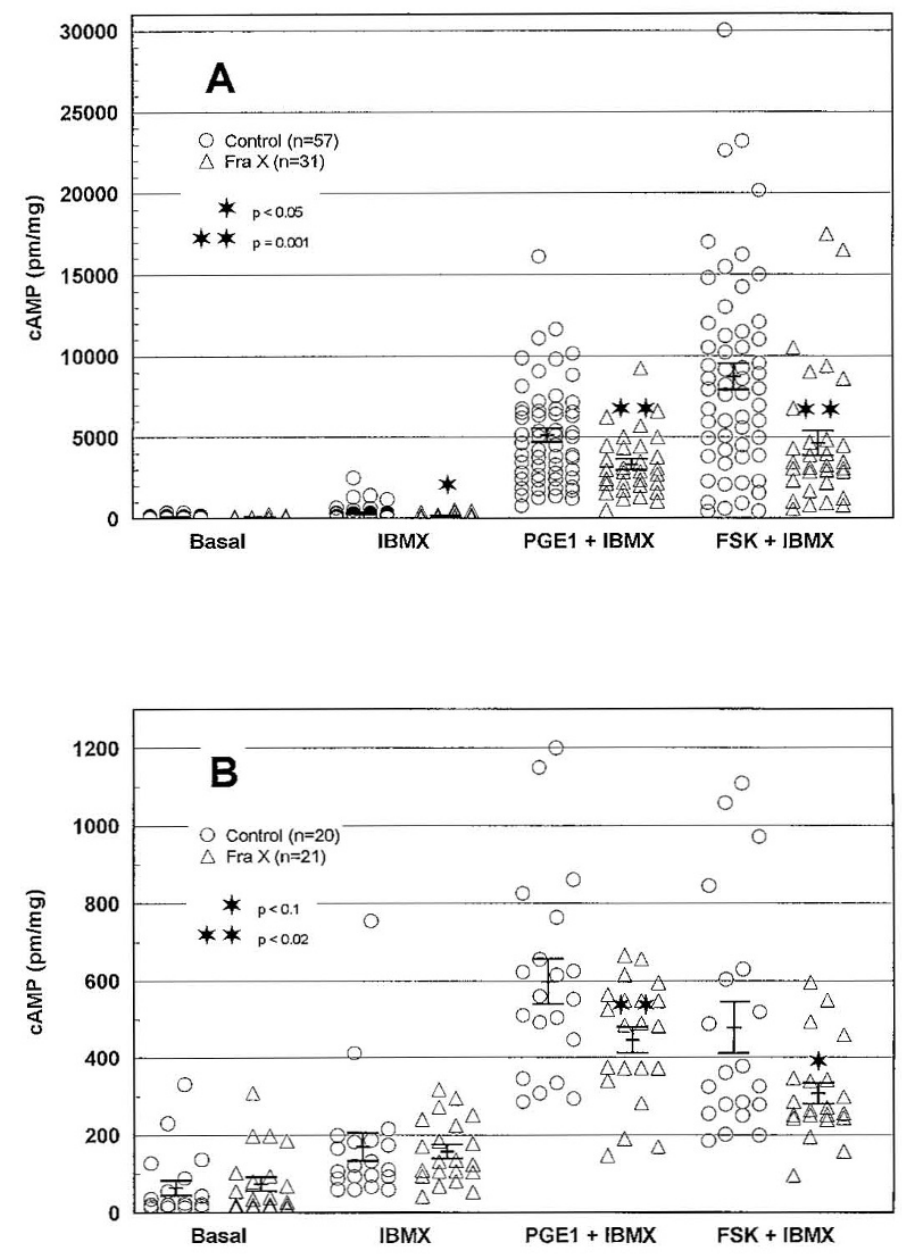

Figure 1. cAMP production in platelets $(A)$ and $\mathrm{LCL}(B)$ from fragile $\mathrm{X}$ and control individuals. Platelet data were adapted from Berry-Kravis and Sklena (10). For both platelets and LCL, IBMX was $1 \mathrm{mM}, \mathrm{PGE}_{1}$ was $10 \mu \mathrm{M}$, and FSK was $50 \mu \mathrm{M}$. Means are indicated by horizontal lines and error bars represent SEM. Values of $p$ were determined by $t$ test.

that, as in platelets $(9,10)$, reduced cAMP production was due to diminished maximum response rather than a shift in potency of reagents.

In a separate single assay (data not shown), LCL from cytogenetically positive fragile $\mathrm{X}$ female carriers with full mutations $(n=3)$ showed lower cAMP production than those from cytogenetically negative females with premutations $(n=$ 3). This was not a statistically significant finding due to low sample number; however, again the magnitude of averaged FSK-stimulated cAMP production was the lowest comparative cAMP measure in the group of full mutation cells.

No relationship was seen between cAMP production and LCL growth rate, measured as $\left[{ }^{3} \mathrm{H}\right]$ thymidine incorporation, in either fragile $\mathrm{X}$ or control cell groups or in the combined group. Passage number was also not correlated with cAMP production in any group. As seen in platelets (10), age and sex of the individual from whom the LCL was derived had no effect on CAMP production in control LCL.

Fragile site percentages in fragile X LCL $(n=19)$ did not correlate with any measure of cAMP production (basal, $r=$ $0.09, p=0.7$; IBMX, $r=-0.18, p=0.46 ; \mathrm{PGE}_{1}, r=-0.12$, $p=0.63$; FSK, $r=0.07, p=0.77$ ). 
Correlation of CAMP production with FMR-1 amplification mutation in fragile $X \boldsymbol{L} C L$. All measurements of cAMP production in fragile X LCL $(n=19)$ except $\mathrm{PGE}_{1}$-stimulated cAMP production were inversely correlated with the maximum (basal, $r=-0.44, p=0.05$; IBMX, $r=-0.55, p=0.01$; FSK; $r=-0.45, p=0.05$ ) and average (basal, $r=-0.385$, $p=0.1$ I IBMX; $r=-0.53, p=0.02$, FSK; $r=-0.48, p=$ $0.03)$ FMR-1 amplified DNA segment length in fragile $X$ mutations. Correlations between cAMP production and average amplified DNA segment lengths are shown in Figure 2. Minimum amplified DNA segment length did not correlate significantly with any measure of cAMP production. Fragile site percentages in fragile X LCL did not significantly correlate with maximum, average, or minimum amplified DNA segment lengths although there was a trend toward higher fragile site percentages in LCL with larger amplification mutations (for average amplified DNA segment length, $r=0.4$ and $p=0.09$ ). Although a few fragile $\mathrm{X}$ patients in this study demonstrated a methylation mosaic pattern in DNA from blood (with a minor
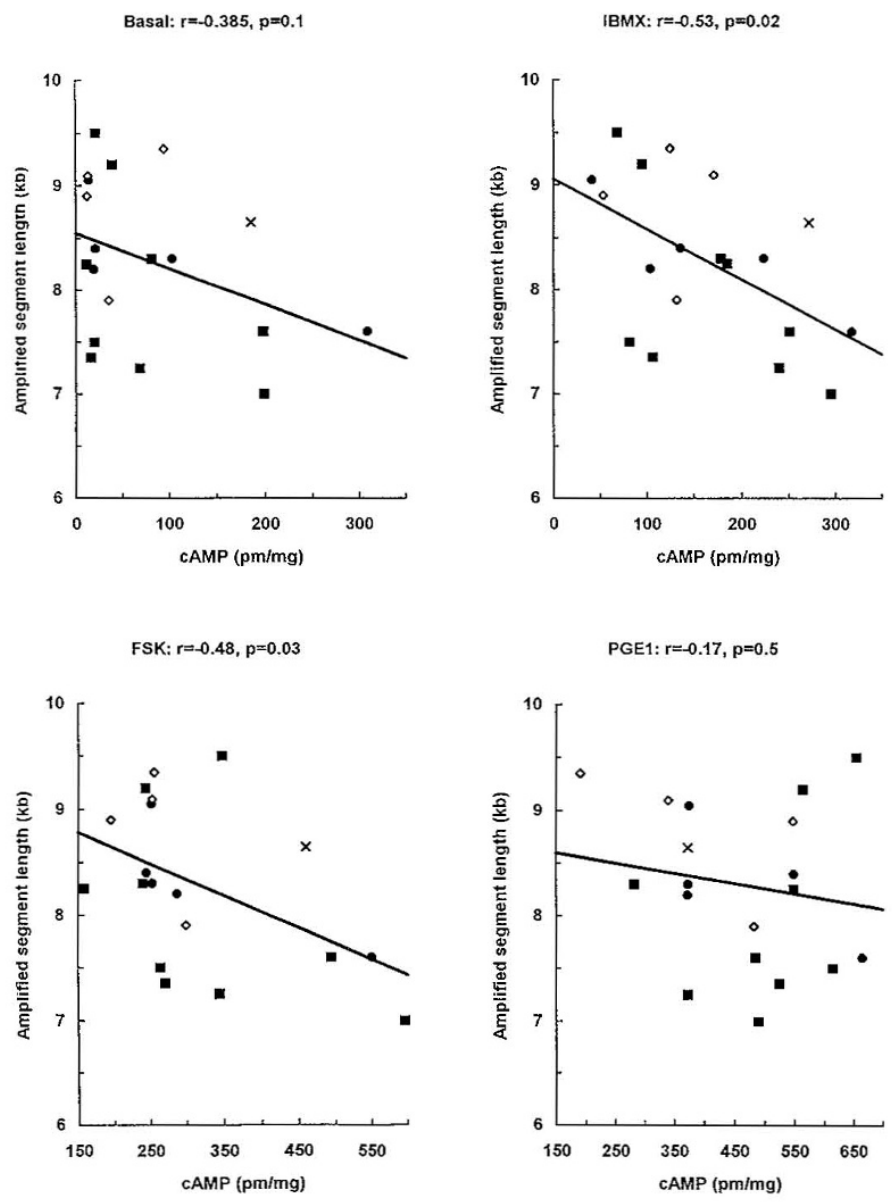

Figure 2. Correlation of cAMP production with average amplified DNA segment lengths in fragile X LCL. Normal FMR-1 DNA segment length in this assay is $5.2 \mathrm{~kb}$, and amplified segments containing fragile $\mathrm{X}$ mutations are larger, often appearing as a smear or multiple bands, in the $6-12-\mathrm{kb}$ range. Average DNA segment lengths represent the size of the midpoint of smears or the average of multiple band sizes. Symbols indicate level of function of fragile $X$ patients from whom cell lines were derived: normal $(X)$, mild impairment $(\bullet)$, moderate impairment (ם), severe impairment $(\diamond)$. Samples in $\mathrm{PGE}_{1}$ and FSK were also in IBMX. Concentrations of reagents are given in the legend to Figure 1 . unmethylated premutation size band), none of the LCL subclones showed premutation or methylation mosaicism-all had completely methylated bands or smears, suggesting complete inactivation of the FMR-1 gene. In agreement with this finding, the RT-PCR assay for FMR-1 mRNA demonstrated normal hypoxanthine-guanine phosphoribosyl transferase product but no FMR-1 product in all fragile X LCL, indicating complete lack of expression of FMR-1 mRNA in these lines. All control LCL expressed FMR-1 mRNA.

In control LCL, the size of the normal FMR-1 repeat sequence (range 21-49 CGG repeats) determined by PCR did not correlate with any measure of cAMP production (basal, $r=$ $-0.09, p=0.69$; IBMX, $r=-0.11, p=0.64 ; \mathrm{PGE}_{1}, r=$ $-0.07, p=0.75$; FSK, $r=-0.03, p=0.89$ ), suggesting the correlation with amplified CGG repeat size is specific to fragile $\mathrm{X}$ cell lines. The control CGG repeat range is small relative to the range (about $300-2300$ repeats) of size variation in fragile $\mathrm{X}$ cells and CGG repeat variation in normal cells is not enough to allow visualization of size differences on Southern blots, on which all of the control EcoRI-digested DNA samples gave the expected $5.2-\mathrm{kb}$ fragment.

There was no relationship between patient IQ and cAMP production, fragile site percentages, or size of amplified DNA segments in fragile X LCL (see Fig. 2). Somatic mosaicism in tissues from fragile $\mathrm{X}$ patients, however, would preclude any conclusions about these potential correlations in brain tissue.

\section{DISCUSSION}

We have described a pattern of diminished cAMP production in platelets $(9,10)$ and now LCL from fragile $X$ patients. Molecular analysis of DNA from fragile X LCL has shown a correlation between measures of cAMP production not associated with receptor stimulation and the length of the fragile $\mathrm{X}$ amplification mutation in these lines. The pattern of decreased cAMP production with FSK-stimulated cAMP production being more affected than $\mathrm{PGE}_{1}$-stimulated production (particularly evident in platelets) suggests decreased activity of a catalytic subunit of adenylate cyclase rather than defective receptor coupling in fragile $X$ tissues. The pattern of fragile $X$ mutation amplified DNA segment length correlations supports this suggestion, with significant correlations with measures of cAMP production which reflect directly the activity of the catalytic subunit of adenylate cyclase and no correlation with $\mathrm{PGE}_{1}$ (receptor)-mediated stimulation of cAMP production.

Of the eight known catalytic subunits of adenylate cyclase, at least types 6 and 7 are expressed in some lymphoid cells (LCL have not been specifically studied), whereas all eight are expressed in brain (24). Platelets express high levels of FSKstimulable cyclase activity, and high affinity FSK binding sites which resemble those in brain and which appear to be related to presence of type 1 cyclase (25), the species most prevalent in brain (26). Platelets therefore represent a more accurate model for studies of regulation and FSK-stimulability of brain cyclases. Levels of stimulable cAMP production are much lower in LCL than platelets and make the CAMP production defect more difficult to demonstrate statistically in fragile $X$ LCL relative to controls, despite a pattern of decreased pro- 
duction which very closely resembles that in platelets. Further, this assay is expected to measure cAMP production by all cyclases expressed in a given tissue. If only some type(s) of cyclases are affected, the magnitude and ease of demonstration of the cAMP production deficiency may vary between tissues depending on levels of expression of the affected cyclase(s).

Certainly there are many clinical features of patients with fragile $\mathrm{X}$ syndrome which might be expected to go along with defective cAMP production. These include the cognitive profile, with particular deficits in short-term memory and sequencing (27), and behavioral problems involving difficulties with habituation and hypersensitivity to environmental stimuli (28). Also, there is thought to be an increased incidence of obesity in the fragile X population (29), and obesity has been shown to be associated with lower cellular accumulation of cAMP (30). Finally, patients with fragile $\mathrm{X}$ syndrome tend to exhibit overgrowth, especially early in life, of a number of body parts including ears and head size (31). Later in life, testes are enlarged. Decreased intracellular cAMP levels might be associated with excessive cellular proliferation due to enhancement of activity of the Ras/Raf cascade (32).

No correlation is seen between cAMP production and fragile site percentages when both are assayed in a single tissue at roughly the same time in culture and under highly standardized conditions. Although we previously reported a correlation between fragile site percentage in lymphocytes and cAMP production in platelets from a small number of fragile $\mathrm{X}$ patients (10), the prior lymphocyte data may have been influenced by dietary or patient factors. The LCL experiments are free of such variables, allow correlation of parameters in a single tissue and therefore are expected to give a more accurate result. It is still possible that higher cAMP production in platelets and lower fragile site percentages in lymphocytes from certain fragile $X$ patients resulted from "methylation mosaicism" in these patients. None of the fragile X LCL examined was methylation mosaic, so this was not a confounding variable in this study.

There was also no significant correlation between length of the amplified DNA segment in the full mutation and percent of fragile sites in the LCL in this study. This is consistent with the correlation of cAMP measures with amplified segment length but not with percent fragile sites. Other investigators $(33,34)$ have published correlations between amplified segment length and percent fragile sites; however these studies include premutation carriers who have smaller mutations and lower or absent cytogenetic expression. Our data are in agreement with that from the large multicenter study of Rousseau et al. (35) which did not demonstrate a significant correlation between percent fragile sites and mutation size when 224 male carriers of a full mutation were analyzed alone.

Recent studies suggest that the 4.8-kb FMR-1 mRNA is alternatively spliced into at least 12 isoforms $(36,37)$ which are mainly identified in the cytoplasm (16) and bind RNA (38), including about $4 \%$ of brain transcripts. Thus, the FMR-1 protein family might theoretically serve to regulate gene products important in neural function through interaction with specific RNAs. Alteration of such regulatory processes might lead to previously documented abnormalities of dendritic spine formation (39) and regional neuroanatomical abnormalities observed in fragile $X$ brain (40). The FMR-1 protein could regulate activity of one or several of the eight adenylate cyclases expressed in brain as well as other signal transduction systems through interaction with specific RNA. This hypothesis provides an attractive explanation for the finding of overall diminished cAMP production in several fragile $\mathrm{X}$ tissues but the effect of mutation size on cAMP production is difficult to explain on this basis, as all fragile X LCL appear to be equally and completely lacking in expression of the FMR-1 protein. It is possible that small, although currently undetectable, amounts of FMR-1 transcription may occur, with more transcription occurring in genes with smaller mutations. This would presuppose exquisite sensitivity of CAMP production to very small amounts of FMR-1 protein. Diminished cAMP production would be expected to be better correlated with the degree of methylation at the FMR-1 locus than with size of the mutation. $\mathrm{PGE}_{1}$ and FSK-stimulated cAMP production measured in an LCL from a single patient with an unmethylated full mutation (and 50\% normal FMR-1 protein levels) was intermediate to averaged values from control and fragile X LCL analyzed in the same assay (41). This result would tend to support the concept of a relationship between the FMR-1 protein and cAMP production, but data from a series of such patients would be required before a definitive conclusion could be drawn.

Alternatively, increasing size of unstable DNA in the FMR-1 amplification mutation may be related to diminished cAMP production due to alteration of transcription of genes near FMR-1. Hansen et al. (42) have shown large variable late replication domains at the FMR-1 locus and extending at least $150-\mathrm{kb}^{\prime}$ and $34-\mathrm{kb} 3^{\prime}$ of the expanded CGG repeat, implying that genes in addition to FMR-1 may be affected. It appears, however, that abnormal FMR-1 function is sufficient to produce the phenotype, as a severely affected patient with a point mutation affecting one of the RNA binding domains has been described (43). PGE $_{1}$ and FSK-stimulated cAMP production in an LCL from this patient was intermediate to values from control and fragile $\mathrm{X}$ samples in a single assay. These data do not definitively support either of the above hypotheses and is difficult to interpret on the basis of only one cell line with an FMR-1 point mutation. Again, a series of such lines would be needed.

Further studies with tissues from fragile $X$ patients with varying abnormal replication domain size at FMR-1, with fully or partially unmethylated full mutations and with FMR-1 gene abnormalities other than the CGG repeat amplification mutation may help distinguish between a direct effect of FMR-1 on cAMP cascade function versus diminished cAMP production due to alteration of transcription of a closely linked gene. In either case abnormal cAMP cascade function may contribute to cognitive dysfunction in patients with fragile $\mathrm{X}$ syndrome.

Acknowledgments. DNA probe StB12.3 was obtained from Dr. J.-L. Mandel, Institut De Chimie Biologique, Strassbourg, France. The LCL from patient TR9001 with an FMR-1 point mutation was a generous gift from Dr. B. Oostra, Erasmus University, Rotterdam, The Netherlands. 


\section{REFERENCES}

1. Helper JR, Gilman AG 1992 G proteins. Trends Biochem Sci 17:383-387

2. Levitzki A, Marbach I, Bar-Sinai A 1993 The signal transduction between betaadrenergic receptor and adenylyl cyclase. Life Sci 52:2093-2100

3. Walton KM, Rehfuss RP 1992 Molecular mechanisms of cAMP-regulated gene expression. Mol Neurobiol 3:197-210

4. Emptage NJ, Carew TJ 1993 Long-term synaptic facilitation in the absence of short-term facilitation in Aplysia neurons. Science 262:253-256

5. Kandel ER, Schwartz JH 1982 Molecular biology of learning: modulation of transmitter release. Science 218:433-443

6. Dudai Y 1986 Cyclic AMP and learning in Drosophila. Adv Cyclic Nucleotide Protein Phosphorylation Res 20:343-361

7. Farfel Z, Friedman E 1986 Mental deficiency in pseudohypoparathyroidism type I is associated with $\mathrm{N}_{\mathrm{s}}$-protein deficiency. Ann Intern Med 105:197-199

8. Brook JD, McCurrach ME, Harley HG, Buckler AJ, Church D, Aburatani H, Hunter K, Stanton VP, Thirion J-P, Hudson T, Sohn R, Zemelman B, Snell RG, Rundle SA, Crow S, Davies J, Shelbourne P, Buxton J, Jones C, Juvonen V, Johnson K, Harper PS, Shew DJ, Housman DE 1992 Molecular basis of myotonic dystrophy: expansion of a trinucleotide (CTG) repeat at the $3^{\prime}$ end of a transcript encoding a protein kinase family member. Cell 68:799-808

9. Berry-Kravis E, Huttenlocher P 1992 Cyclic AMP metabolism in fragile X syndrome. Ann Neurol 31:22-26

10. Berry-Kravis, Sklena P 1993 Demonstration of abnormal cAMP production in platelets from patients with fragile X syndrome. Am J Med Genet 45:81-87

11. Brown WT 1990 The fragile X: progress towards solving the puzzle. Am J Hum Genet 47:175-180

12. Verkerk AJMH, Pieretti M, Sutcliffe JS, Fu Y-H, Kuhl DPA, Pizzuti A, Reiner O, Richards S, Vicoria MF, Zhang F, Eussen BE, van Ommen G-JB, Blonden LAJ, Riggins GJ, Chastain JL, Kunst CB, Galjaard H, Caskey CT, Nelson DL, Oostra BA, Warren ST 1991 Identification of a gene (FMR-1) containing a CGG repeat coincident with a breakpoint cluster region exhibiting length variation in fragile $X$ syndrome. Cell 65:905-914

13. Fu Y-H, Kohl DPA, Pizzuti A, Pieretti M, Sutcliffe JF, Richards S, Verkerk AJMH, Holden JJA, Fenwick Jr RG, Warren ST, Oostra BA, Nelson DL, Caskey CT 1991 Variation of the CGG repeat at the fragile $X$ site results in genetic instability and resolution of the Sherman paradox. Cell 67:1047-1058

14. Oberlé I, Rousseau F, Heitz D, Kretx C, Devys D, Hanauer A, Boue J, Bertheas MF, Mandel J-L 1991 Instability of a 550-base pair DNA segment and abnormal methylation in fragile X syndrome. Science 252:1097-1102

15. Pieretti M, Zhang F, Fu Y-H, Warren ST, Oostra BA, Caskey CT, Nelson DL 1991 Absence of expression of the FMR-1 gene in fragile X syndrome. Cell 66:817-822

16. Devys D, Lutz Y, Rouyer N, Bellocq J-P, Mandel J-L 1993 The FMR-1 protein is cytoplasmic, most abundant in neurons and appears normal in carriers of a fragile $\mathrm{X}$ premutation. Nat Genet 4:335-340

17. McConkie-Rosell A, Lachiewicz AM, Spiridigliozzi GA, Tarleton J, Schoenwald S, Phelan MC, Goonewardena P, Ding X, Brown WT 1993 Evidence that methylation of the FMR-1 locus is responsible for variable phenotypic expression of the fragile $X$ syndrome. Am J Hum Genet 53:800-809

18. Lowry OH, Rosebrough NJ, Farr AL, Randall RJ 1951 Protein measurement with the Folin reagent. J Biol Chem 193:265-275

19. Brooker G, Harper JF, Terasaki WL, Moylan RD 1979 Radioimmunoassay of cyclic AMP and cyclic GMP. Adv Cyclic Nucleotide Res 10:1-33

20. Rousseau F, Heitz D, Biancalana V, Blumenfeld S, Kretz C, Boue J, Tommerup N, Van Der Hagen C, DeLozier-Blanchet C, Croquette M-F, Gilgenkrantz S, Jalbert P, Voelckel M-A, Oberlé I, Mandel J-L 1991 Direct diagnosis by DNA analysis of the fragile X syndrome of mental retardation. N Engl J Med 325:1673-1681

21. Levinson G, Maddalena A, Palmer FT, Harton GL, Bick DP, Howard-Peebles PN, Black SH, Schulman JD 1992 Sizing fragile X permutations and normal alleles with nested PCR. In: Hagerman RJ, McKenzie P (eds) International Fragile X Conference Proceedings. Spectra Publishing, Dillon, CO, p 385
22. Chomczynski P, Sacchi N 1987 Single-step method of RNA isolation by acid guanidinium thiocyanate-phenol-chloroform extraction. Anal Biochem 162:156-159

23. Gibbs RA, Nguyen P-N, McBride LJ, Koepf SM, Caskey CT 1989 Identification of mutations leading to the Lesch-Nyhan syndrome by automated direct DNA sequencing of in vitro amplified cDNA. Proc Natl Acad Sci USA 86:1919-1923

24. lyengar R 1993 Molecular and functional diversity of mammalian $\mathrm{G}_{\mathrm{s}}$-stimulated adenylyl cyclases. FASEB J 7:768-775

25. Krupinski J, Lehman TC, Frankenfield CD, Zwaagstra JC, Watson PA 1992 Molecular diversity in the adenylylcyclase family: evidence for eight forms of the enzyme and cloning of type VI. J Biol Chem 267:24858-24862

26. Sutkowski EM, Tang W-J, Broome CW, Robbins JD, Seamon KB 1994 Regulation of forskolin interactions with type I, II, V, and VI adenylyl cyclases by $\mathrm{G}_{\mathrm{s} \alpha}$. Biochemistry 33:12852-12859

27. Freund LS, Reiss AL 1992 Cognitive profiles associated with the fra(X) syndrome in males and females. Am J Med Genet 38:542-547

28. Hagerman RJ, Jackson III AW, Levitas A, Rimland B, Braden M 1986 An analysis of autism in fifty males with the fragile X syndrome. Am J Med Genet 23:359-374

29. Laing S, Partington M, Robinson H, Turner G 1991 Clinical screening score for the fragile X (Martin Bell) syndrome. Am J Med Genet 38:256-259

30. Martin LF, Klim CM, Vannucci SJ, Dixon LB, Landis JR, LaNoue KF 1990 Alterations in adipocyte adenylate cyclase activity in morbidly obese and formerly morbidly obese humans. Surgery 108:228-235

31. Butler MG, Brunschwig A, Miller LK, Hagerman RJ 1992 Standards for selected anthropometric measurements in males with the fragile $\mathrm{X}$ syndrome. Pediatrics 89:1059-1062

32. Cook S, McCormick F 1993 Inhibition by cAMP of ras-dependent activation of raf. Science 262:1069-1072

33. Snow K, Doud L, Hagerman R, Hull C, Hirst MC, Davies KE, Thibodeau SL 1992 Analysis of mutations at the fragile $\mathrm{X}$ locus using the DNA probe Ox 1.9. Am J Med Genet 43:244-254

34. Smits A, Smeets D, Dreesen J, Hamel B, de Haan A, Van Oost B 1992 Parental origin of the fragile $\mathrm{X}$ gene is a major determinant of the cytogenetic expression and the CGG repeat length in female carriers. Am J Med Genet 43:261-267

35. Rousseau F, Heitz D, Tarleton J, MacPherson J, Malmgren H, Dahl N, Barnicoat A, Mathew C, Mornet E, Tejada I, Maddalena A, Speigel R, Schinzel A, Marcos JAG, Schorderet DF, Schaap T, Maccioni L, Russo S, Jacobs PA, Schwartz C, Mandel JL 1994 A multicenter study on genotype-phenotype correlations in the fragile $X$ syndrome, using direct diagnosis with probe StB 12.3: the first 2,253 cases. Am J Hum Genet 55:225-237

36. Ashley CT, Sutcliffe JS, Kunst CB, Liener HA, Eichler EE, Nelson DL, Warren ST 1993 Human and murine FMR-1: alternative splicing and translation initiation dowstream of the CGG-repeat. Nat Genet 4:244-251

37. Eichler E, Richards S, Gibbs RA, Nelson DL 1993 Fine structure of the human FMR-1 gene. Hum Mol Genet 2:1147-1153

38. Ashley CT, Wilkinson KD, Reines D, Warren ST 1993 FMR1 protein: conserved RNP family domains and selective RNA binding. Science 262:563-566

39. Wisniewski KE, Segan SM, Miezejeski CM, Sersen SM, Rudelli RD 1991 The fra(x) syndrome: neurological, electrophysiological, and neuropathological abnormalities. Am J Med Genet 38:476-480

40. Reiss AL, Lee J, Freund L 1994 Neuroanatomy of fragile X syndrome: the temporal lobe. Neurology 44:1317-1324

41. Merenstein S, Shyu V, Sobesky W, Staley L, Berry-Kravis E, Nelson DL, Lugenbeel KA, Taylor AK, Pennington BF, Hagerman RJ 1994 Fragile X syndrome in a normal IQ male with learning and emotional problems. J Am Acad Child Adolesc Psychiatry 33:1316-1321

42. Hansen SR, Canfield TK, Lamb MM, Gartler SM, Laird CD 1993 Association of fragile X syndrome with delayed replication of the FMR-1 gene. Cell 73:1403-1409

43. De Boulle K, Verkerk AJMH, Reyniers E, Vits L, Hendrick J, Van Roy B, VanDenBos F, de Graff E, Oostra BA, Willems PJA 1993 Point mutation in the FMR-1 gene associated with fragile $X$ mental retardation. Nat Genet 3:31-35 